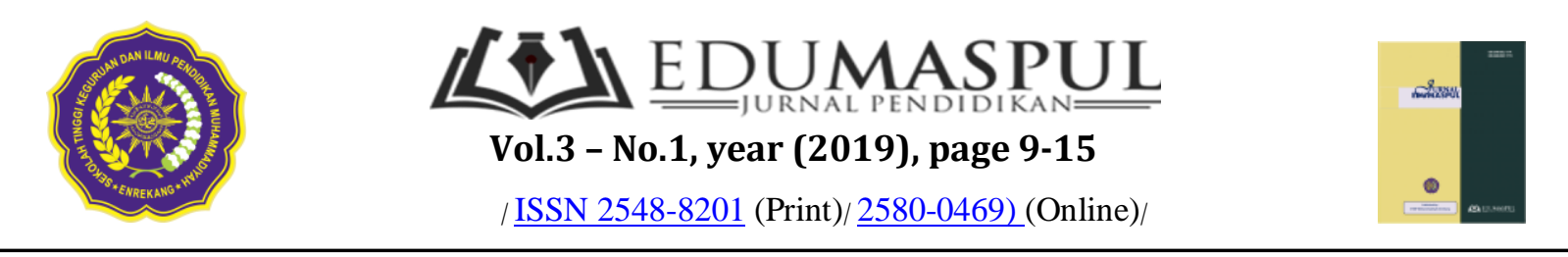

\title{
APPLICATION DRAMA TECHNIQUE IN DEVELOPING SPEAKING OF THE ELEVENTH GRADE STUDENTS OF MAN MAJENE
}

\author{
ABDUL RAHMAN R. \\ (English Education department, Indonesia).
}

* Corresponding Author. E-mail: ${ }^{1}$ mamanr306@gmail.com

\begin{tabular}{|l|l|l|} 
Receive: 05/Januari/2019 & Accepted: 15/Maret/2019 & Published: 02/April/2019
\end{tabular}

\begin{abstract}
Abstrak
Penelitian ini bertujuan untuk membuktikan apakah penerapan teknik drama mampu mengembangkan keterampilan berbicara siswa.Desain penelitian ini adalah desain eksperimen. Ada dua kelompok: eksperimen dan kontrol. Penelitian ini dilakukan di Madrasah Aliah Negeri Majene, dan mengambil 40 siswa sebagai sampel. Data dikumpulkan dengan menggunakan pre-test, perawatan, dan post-test. Tes berbicara diberikan kepada siswa kelas eksperimen dan kontrol. Skor dinilai oleh tiga penilai. Data dianalisis dan diinterpretasikan dengan menggunakan Pearson Product Moment dibantu oleh program perangkat lunak SPSS 20 (Paket Statistik untuk Layanan Solusi). Hasil penelitian mengungkapkan bahwa penerapan teknik drama dapat dibuktikan untuk mengembangkan keterampilan berbicara siswa dan penerapan teknik drama mengembangkan keterampilan berbicara siswa.Hasil pengembangan skor berbicara siswa dari pre-test ke post test menunjukkan perbedaan yang signifikan. Peneliti menemukan bahwa sig. (2 tailed) adalah 0,000 yang lebih rendah dari 0,05. Hasil perbandingan perkembangan berbicara siswa antara kelompok eksperimen dan kontrol adalah 0,025. Ini berarti perkembangannya signifikan. Penerapan teknik drama dikembangkan dan meningkatkan keterampilan berbicara siswa. Temuan ini menandakan bahwa penerapan teknik drama direspon secara positif oleh kelas eksperimen.
\end{abstract}

\section{Developing speaking skill!}

\section{Abstract (English-Indonesia)}

This research aims to proof whether the application of drama technique is able to develop students' speaking skill.The design of this study is experimental design. There were two groups: experimental and control group. The research was conducted at Madrasah Aliah Negeri Majene, and took 40 students as samples. The data were collected by using the pretest, the treatment, and the post-test. The speaking test administered to the students of experimental and control class. The scores were assessed by three assessors. The data were analyzed and interpreted by using Pearson Product Moment assisted by SPSS 20 (Statistical Package for Service Solution) software program. The result of the research reveals that application of drama technique can be proven to develop students'speaking skill and the 
application of drama technique develop students' speaking skill. The result of the students' speaking score development from pre-test to post test demonstrates a significant difference. The researcher found that sig. (2 tailed) is 0.000 which is lower than 0.05. The outcome of the students' speaking development comparison between experimental and control group is 0.025. It means that the development is significant. The application of drama technique developed and improve students' speaking skill. The finding signifies that application of drama technique is responded positively by the experimental class.

\section{Keywords: Developing; speaking; skill}

\section{Pendahuluan (10\%)}

Teaching of English at senior high school especially in MAN Majene chiefly aims at three other skills. It is overlooked that the oral skill is actual and is also very important for students. But how to make students are interested to speak English in the class? It is not easy most students like to be a listener. Why? Because many factors can hamper them in learning English especially speaking skill. First, the students are usually ashamed, awkward and afraid in speaking English with their friends, or their teacher. Second, they find difficulties to pronounce English word and express their ideas in English. Besides the students lack practice so that they are difficult to find out the situation in which they practice their English more fluently. It is important to make the students are interested to speak English, the teacher will need to give the students sufficient opportunities to practice the speaking skill or certain method which is expected to activate the students in speaking English. Drama as literay works is expected to influence the students' speaking skill, and also that activity was expected to improve students' speaking English ability.

In relation of the statement above, the researcher was interested and focused on the attention to the ability of the elevnth grade students of MAN Majene in speaking through local drama as literary works.

Unlike fiction or poetry, drama is written not to read but to do or to act out. According to Barnet, et al: (1992), drama is an imitation of an action. Drama has advantages, as a performance on stage, drama presents a life in a real form through a set of dialogues and the audience can directly see the characters (actors and actris).

\section{Literature Review}

\section{a. The Nature of Speaking}

Speaking is a means of oral communication in giving ideas or an information to others. It is the most essential way in which the speaker can express himself through the language. Widdowson (1985) stated that acts of communication through speaking are commonly performed in face to face interaction and occur as a part of dialogue or rather form of verbal exchange.

One of the aspect of speaking is fluency. Speaking fluency is an aspect of oral communication to express human idea, feeling, opinion, and thought or information which helps people to communicate one another without hesitation, repetion, and false start. In one of the first studies investigating fluency, Fillmore (1997) quoted by Kormos and Denes (2009), conceptualized fluency in four different ways. First, he defined fluency as the ability to talk at length with few pauses and to be able to fill the time with talk. Second, a fluent speaker is not only capable of talking without hesitation but expressing his/her message in a coherent, reasoned and semantically densed manner. Third, a person is considered to be fluent if he/she knows what to say in a wide of range of contexts. Finally, Fillmore (1997) argued that fluent speaker are creative and 
imaginative in their language use and maximally fluent speaker are creative and imaginative in their language use and a maximally fluent speaker has all of the above mentioned abilities. Fillmore's definition of fluency is very extensive, but it is unclear how this conceptualization differs from the definition of global oral proficiency.

According to Chaney, speaking is the process of building and sharing meaning through the use of verbal and nonverbal symbols, in a variety of contexts.

While another expert, Theodore Huebner said . Language is essentially speech, and speech is basically communication by sounds. And according to him, speaking is a skill used by someone in daily life communication whether at school or outside. The skill is acquired by much repetition; it primarily a neuromuscular and not an intellectual process. It consists of competence in sending and receiving messages.

\section{b. Drama Technique}

Drama is defined as technique to communicate or convey the intended meaning which involves a wide range of activities (Via, 1987). Drama refers to a work of art which will be exploited as a resource for language learning in the present study. Therefore, it is worth noting that these two terms will be used interchangeably throughout this study. The benefits of drama techniques or drama to speaking development are extensively acknowledged. According to Hamilton and McLead (1993), drama is beneficial especially to speaking development.

Elements of drama, according to DiYanni 2000), consist of plot, the sequence of events, character development (the element which makes things happen in drama), dialogue (which functions in advancing the plot, creating settings, and revealing character), staging (the presentation of drama in performance), and theme (the central idea or motif of the play). Meanwhile, drama techniques utilized in a language class have generally been divided into seven types, including games, mine or pantomime, role playing, improvisation, simulation, storytelling, and dramatization. The present study combined drama elements and types of drama techniques into an arrangement of instruction in order to broaden learners' opportunities for nourishing their speaking abilities.

\section{Reseach Question}

Is application of drama technique able to develop students' speaking skill of the eleventh grade of MAN Majene?

\section{RESEARCH METHODOLOGY}

\section{A. Participants}

The population of this research was the eleventh grade students of MAN Majene in academic year 2013/2014 that consisted of four classes and each class has various numbers of students that was about 20 students. The total number of population were 80 students.

\section{B. Instrument}

To knew the effectiveness of teaching speaking skill through application of drama technique, the Reseacher gave speaking test to the students. Because the test was speaking test, the reseacher divided the score into three criteria, which were the scores of accuracy, fluency and comprehension. Each criteria, then, it was rated into five scale of rating scores, it was based on David P. Haris. scale rating scores.1After that, to got the mean, the scores from all criteria were sum and divided into five. The pre-test had been given before the treatment was given. Moreover, the post-test was given after he had given the treatment to the class.

\section{Data Collection}


One important thing in this research is to collect the data that can determine the result of the research. The procedures of data collecting used in this research are:

\section{Pre-Test}

The researcher gave the pre-test to the students. The pre-test was in speaking test form. The test consists of 10 questions. The scores were taken in five criteria, which were the scores of accuracy, fluency and comprehension. Then, to get the mean, the scores from all criteria were sum and divided into five. There were three phase that would apply in processing drama technique they are:

\section{a) Presentation Stage}

In the presentation stage, the researcher assigns roles to the students and divides them into three groups. Then, the reseacher explains their roles, the situation that the students have to do in the performance of the drama and the goal or outcome that they have to get. The researcher also must not forget to clarify the cues and gave the example model of the character that the students perform. Finally, the researcher sets the time limit and encourages students to be creative and use their own language resources by working on local drama the story of Andi Depu one of National hero in Mandar and as the first women to be a king in Balanipa kingdom.

The method that was used in this presentation stage was discourse method that was submitting information or description concerning with the root of matter verbally.

\section{b) Practice Stage}

In this stage, the reseacher asked the students to began the performance of local drama while he went around the class checking and giving help as the students needed. Here were the brief explanations of the activities.

The method that was used in this stage was experiment method. It was used to made the students able to communicate with others by using their own language based on the cues that had been given by the researcher before.

\section{c) Production Stage}

In this stage, the researcher asked the students about the outcome of their performance with local drama. Next, the researcher gave feedback on grammar or pronunciation problems that she heard then asked the students to perform the drama in front of the class. Below ere the explanations of this stage:

The method that was used in this final stage was dialogue method. It was used to know the students. speaking ability and their understanding concerned with the subject.

\section{Post-Test}

The reseacher gave the post-test to the students. The test was similar with the pre-test. However, the post-test was given after the treatment had been done by teaching speaking using drama technique. The scores were taken in five criterias, they were: Accuracy, fluency and comprehension. Then, to get the mean, the scores from all criteria are sum and divided into four.

\section{Data Analysis}

a. Scoring

The students' answer from the interview were transcribed. The transcription was subject to analysis using the following criteria level introduced by Heaton (1988).

The converting of students score in speaking skill

$$
\begin{aligned}
& \text { Score } \\
& =\frac{\text { the total of the students' correct answer }}{\text { the total of items }} \times 100
\end{aligned}
$$

To explore the means score of development the students' speaking skill, the researcher used percentage technique. In determining of percentage classification, the means score clasified into seven levels as follow: 


\begin{tabular}{|l|c|c|}
\hline No & Clasification & Score \\
\hline 1 & Excelent & $96-100$ \\
2 & Very good & $86-95$ \\
3 & Good & $76-85$ \\
4 & Farly good & $66-75$ \\
5 & Fair & $56-65$ \\
6 & poor & $35-56$ \\
7 & Very poor & $0-36$ \\
\hline & & \\
\hline
\end{tabular}

Depdiknas 2008:38

b. Calculating the Mean Score and Standard Deviation

Calculating the mean score, standard deviation, frequency table and t-test between speaking skill of the experimental group and control group by using SPSS program version 20.0

\section{FINDINGS AND DISCUSSION}

The findings that the researcher reported in this chapter is based on the analysis of data collection by using test; they are pretest and posttest for experimental group and control group. The result is described based on the problem statements after conducting the research for six meetings.

\section{Scoring Clasification of the Students' Pre-test and Post-test \\ In this part, reseacher presented} the students' pre-test and post-test score in terms of accuracy, fluency, and comprehensibility to see the frequency and precentage.

1) The Students' Accuracy Score in Pre-test and Post-test

The Mean Score and Standard Deviation of the Students' Pre-test and Posttest in Terms of Accuracy.

\begin{tabular}{|l|l|l|l|}
\hline & Mean & N & $\begin{array}{l}\text { Std. } \\
\text { deviation }\end{array}$ \\
\hline Experimental & 69.95 & 20 & 7.77 \\
& 80.10 & 20 & 4.90 \\
\hline Control & 69.10 & 20 & 6.40 \\
& 73.30 & 20 & 7.69 \\
\hline
\end{tabular}

The meanscore and standard deviation were shown the different of pre-test and posttest. Table 4.3 ilustrated that the meanscore of pre-test and post-test were different after giving the treatment. It means that there is an improvement after giving the treatment. The table indicated that the meanscore of the students, pre-test in experimental group is 69.95 fairly good and standard deviation was 7.77, and in post tests is 80.10 (Good) and standard deviation was 4.90 . Meanwhile, the mean score of the students' pre-test in control group is 69.10 (fairly good) and standard deviation is 6.40, and in post-test the meanscore 73.30 (fairly good) and standard deviation is 7.69. It means that the the meanscore of both pre-test and posttest are different after the treatment is done. It shown that the mean score of post-test after the treatment is done has significanc different with score in pre-test.

The result of data analysis of students' improvement on pre-test and posttes of both experimental and control groups in terms of fluency are described in the figur

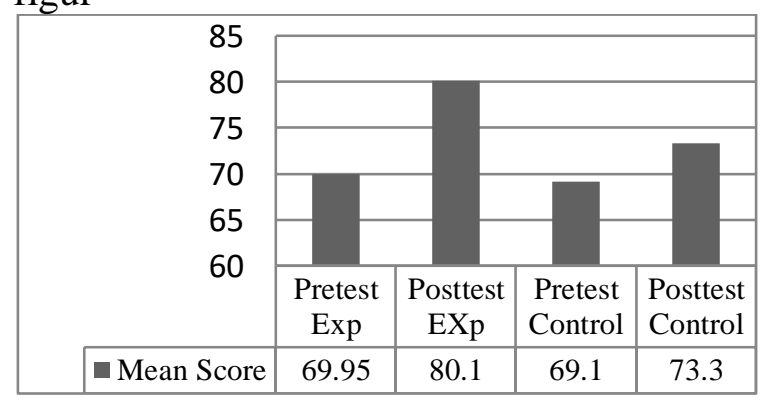

The data that presented in findings were collected and analyzed with SPSS 20.0 and the findings were explained using tables. The scores obtained from the pretest and post-test given to the control and 
experimental groups, as well as the subsequent means and standard deviation, are presented in Table 1. Prior to conducting the experiment, a t-test was used to determine if there were differences at the eleventh grade students of MAN Majene (academic performance) of the experimental and control groups. There was no significant difference at the significance level of $p<0.05$ between the experiment and the control groups.

\section{CONCLUSION}

The development of the students' speaking skill through the application of drama technique in teaching and learning process can be indicated as follows; The first, development of students' participation has occured, the athmosphere of learning process has increased in this case, all the students got the same chance to practice the script of the drama. The second, the students talked a lot. In this part, students talked a lot in practicing to speak English by performing the drama in dialogue form in addition, the situation of the clasroom was alive. The class was full of laugh and the students were enjoyed the teaching and learning process.

Based on the result of speaking tested between pre-test and post-test, it could be proved that there was a development of the students' speaking ability. Having done the treatment, the students' score is higher doing the treatment is higher than the students score before doing the treatment. It means that teaching speaking skill through application of drama technique really effective to develop the students' speaking skill.

\section{BIBLIOGRAPHY}

A. L. Chaney and T. L. Burke, (Boston: Allyn \&Bacon, 1998), p. 13 Teaching Oral Communication in Grades $K-8$,
Apriliaswati R. 2010. Teaching English speaking fluency by using drama.

Brighton, Ciera. 2012. The benefits of using drama in teaching. Thesis, 2012

Budden, Joanna. 2006. Role Play. UK, London: BBC

Byrne, Donn. 1986. Teaching Oral English: Longman Handbooks for English Teacher. Singapore: Longman Group.

Crookal, D. and R.L. 1990. Oxford, Simulation, Gaming and Language Learning.New York: Newbury House,

Cox, Carole. 1999. Teaching LanguageArt. California State University: Long Beach.

DiYanni, R. 2000. Drama: An introduction. Boston: McGraw-Hill.

Doff, Adrian. 1988 Teach English: A Training Course for Teachers Trainer.sHandbooks. The British Council: Cambridge University Press Inc.

Donough, Jo Mc. and Christoper Show 1993. Material and Method in ELT: Applied Language Studies. Cambridge: Blackwell.

Dougill, J. 1987. Drama activities for language learning. London: Macmillian.

Edge, Julian. 1993. Essential of English Language Teaching. Longman.

Hamilton, J. and McLead, A. 1993. Drama in the languages classroom. London:

Center for Information on Language Teaching and Research. 
Haris, David P, Testing English as a Second Language, New York: Mc. Graw Hill Book Company, 1969.

Harmer, Jeremy. 1983. The Practice of English Language Teaching: Longman Handbooks for Language Teaching. USA: Longman Inc.

Huebner, Theodore.1960. Audio Visual Technique in Foreign Language. New York: Cambridge University Press.

House, Susan. 1997. An Introduction to Teaching English to Children. Richmond Publishing.

J.S. Atherton.2003. Learning and Teaching: Exercises: Role Play. United Kingdom.

Kayi, Hayriye. 2006. Teaching Speaking: Activities to Promote Speaking in a Second Language. The Internet TESL Journal, Vol. XII, No. 11.

\section{Curriculum vitae}

The witer was born October 8th, 1984 in Mamuju. He is the son of Abdul Rasyid and Bungaintan, he started his study at elementary school in SD Negeri Lumu Mamuju and graduated 1998. He continued his study to Junior high school at SMPN 4 Majene and graduated in 2001. And then he continued his study to senior high school at state Islamic senior high school of Majene and graduated in 2004, he was accepted as student of English education program, Faculty of language and literature at State University of Makassar and graduated in 2009. In 2012 he continued his study to post graduated at UNM and graduated on 2014. At 2009 he taught at SMA 3 Majene untill 2012 and 2013 he has been teaching at state Islamic Senior high school until now and he also accepted as English lecturer at UNIKA Mamuju. 